\title{
Chinese Higher Education in the Time of MOOCs
}

\author{
Chunying Zhang \\ Department of Foreign Languages and Cultures, Beijing \\ Wuzi University \\ Beijing, China \\ Zhangchunying1979@sina.com
}

\author{
Weihong Zhang \\ English Department, Hebei Tourism Vocational College \\ Chengde, China \\ mayzhwh@126.com
}

\begin{abstract}
The present study intended to search for a way for Chinese higher education to have a better development with the help of MOOCs and survive in the time of MOOCs. This study gave a general introduction to MOOCs and described the global development of MOOCs, pointing out the strong points of MOOCs and the weak points of the traditional classroom teaching model. Meanwhile, this paper discussed the reasons for the surge in interest in MOOCs in Chinese higher education institutions and then elaborated on the opportunities and challenges faced by Chinese higher education and emphasized that the main purpose of building a new pattern of localized MOOCs in China was to improve the teaching quality with the aid of MOOCs. This article suggested that if Chinese higher education institutions want to survive in the MOOCs trend, they must actively look for ways to change the status quo and get improvement.
\end{abstract}

Keywords-MOOCs; High Education; Teaching Quality; Challenges; Opportunities

\section{INTRODUCTION}

MOOC (Massive Open Online Course) is an acronym that stands for massive open online course. It is a free Web-based distance learning program that is designed for the participation of large numbers of geographically dispersed students [1].

In principle, a MOOC is denoted as:

Massive relates to the large number of students (users) who simultaneously take courses; the focus of MOOCs being here on scalability and building a learning community.

Open relates to open registration (no prerequisites) and open content (free of charge accessible), although some providers offer their services for profit in exchange for college credits.

Online describes the used communication platform (Web 2.0), providing real time interaction (group collaboration) or automated feedback.

Courses relates to the value proposition, the learning resources (items), most of them self-paced, leading to certification, some (with start/end dates and offered for profit) leading to college credits [2]. The goal of education is to help learners develop the knowledge, skills and attitudes to become effective problem solvers, independent critical thinkers, lifelong learners, and responsible me mbers of society [3] argued so clearly, experience plays a central and critical role in that development [4] .

The educational ideas of the MOOCs conform to the educational philosophy promoted by Confucius that is to provide educational access to all. It is the personalized education. New York Times columnist Thomas Fried man described them as an educational "revolution," while the Washington Post suggested they could provide "elite education for the masses." Some businesses see the potential for bridging the "skills gap" between workers and employers, while universities view online offerings as a way to maximize the value of their branded pedagogical content and potentially shore up revenue [5].

\section{THE GLOBAL DEVELOPMENT OF MOOCS}

The term MOOC originated in Canada. In 2008, Dave Cormier, an instructional technologist at the University of Prince Edward Island coined the term "MOOC" to describe George Siemens' and Stephen Downes' course called "Connectivism and Connectivist Knowledge." George Siemens, a researcher at the University of Manitoba ran the first MOOC with Stephen Downes, a researcher with the National Research Council of Canada. This course was presented to 25 tuition-paying students at the University of Manitoba and at the same time attracted around 2,300 students from the general public who took the online class at no cost. They may work on lessons through the internet. Meanwhile, they can participate and engage in online discussions as well. MOOCs offer great convenience to the students with great enthusiasm for learning who are bounded by time and money. Since 2008, MOOCs have soared in popularity as the "disruptive innovation". MOOCs have become a hot topic in education and learning. Called the "Most Important Educational Technology in 200 Years" by the head of a new consortium of Harvard and MIT offering MOOCs, forecasts of fundamental changes in higher education are as common as iPads in a Starbucks [6].

To date, the MOOCs that have drawn the largest crowds have been taught by high-profile instructors on popular topics. A recent MOOC at Stanford University,

"Introduction to Artificial Intelligence," taught by AI experts Sebastian Thrun and Peter Norvig, drew a worldwide open enrollment well in excess of 100,000 students[7].

This "tsunami" started in the fall of 2011 when two Stanford University professors, Sebastian Thrun and Peter Norvig, offered their "Introduction to Artificial Intelligence" course online to anyone for free. Over 160,000 students in more than 190 countries were enrolled 
and not much later, Udacity was born, which is one of the three largest MOOC providers. By April 2013, the online leading company Udacity had offered 24 courses, with 90,000 students registered in its first two classes alone. The second one is Coursera that was founded by two Stanford University computer science professors, Daphne Koller and Andrew Ng in April 2012. By June 2013, Coursera had agreements with 70 higher education partners including Stanford and Princeton. In December, Massachusetts Institute of Technology (MIT) offered a special certificate, known as MITx, for people who complete certain online courses. Harvard University jumped in as an equal partner to a nonprofit, open-sourced joint online learning venture called edX that was launched in May 2012. By the end of 2013, 575 MOOCs involving 25 subjects have been unveiled on the Coursera platform.

Due to the bran-new teaching mode, MOOCs have been taking the worlds of higher education by storm in China since 2013. According to statis tics provided by Coursera in 2012, the Chinese audience is the fourth largest consumer of its free online courses, behind the U.S., Brazil, and India. In April 2013, Hong Kong University launched the course in Coursera, is considered as the first MOOC in Asian. On the 21st of May, Peking University and Tsinghua University announced to join in edX. On July 8, Fudan University and Shanghai Jiaotong University joined in Coursera. Not much later, 12 Chinese top universities announced to launch Chinese-language-designed MOOCs platforms together. Peking and Tsinghua universities unveiled their first MOOCs in September. Tsinghua University launched its own platform called http://XuetangX.com, to host local MOOCs as well as courses on the edX platform of Harvard and the Massachusetts Institute of Technology[8].Nowadays, MOOCs are attracting more and more universities and continue to mushroom in China.

\section{REASONS FOR THE SURGE IN INTEREST IN MOOCS IN CHINESE HIGHER EDUCATION INSTITUTIONS}

It is generally known that the social teaching tradition of modern school education can trace back to the Great Didactic written by the Czech educator Johann Amos Comenius in 1632. The Great Didactic was the springboard for the formal classroom-based teaching methodology in terms of space, time, personnel, etc. with certain restrictions such as textbook, teachers and students. Comenius created the school system and invented a system of classroom teaching[9]. According to the traditional classroom teaching, there must be a classroom and desks. The textbook is the crystallization of knowledge so the content is limited. The criticisms of lecture style teaching can be summarized by a quote attributed to Mark Twain:

"College is a place where a professor's lecture notes go straight to the student's lecture notes, without passing through the brains of either.[10]" Many scholars described the typical classroom teaching as a laborintensive production mode because the teaching materials are same and students just like soldiers obey orders who lack innovation ability and independent thinking ability. It is the Age of Big Data now. The Age of Big Data needs a large number of creative youth which requires us to break through the traditional barriers. In the current era of knowledge explosion, the old traditional teaching with boundary limitation can't keep pace with the rapid development of information society any more.

MOOCs is different from the the traditional classroom teaching. The table below presents the comparis on of MOOCs to traditional teaching and learning[11].( See Fig. 1)MOOCs are the disseminule of higher education driven by elite universities. On MOOCs platforms, all kinds of courses are offered. The courses mainly consisted of short video lectures, exercises, and discussion forums. Classroom teaching, students learning process, students' learning experience and interaction between teachers and students are implemented online systematically.

\begin{tabular}{|c|c|c|}
\hline Items & MOOCs & $\begin{array}{l}\text { Traditional } \\
\text { teaching and } \\
\text { learning }\end{array}$ \\
\hline $\begin{array}{l}\text { student } \\
\text { numbers }\end{array}$ & $\begin{array}{l}\text { Unlimited, millions } \\
\text { of students }\end{array}$ & $\begin{array}{ll}\text { dozens } & \text { or } \\
\text { hundreds } & \text { of } \\
\text { people } & \\
\end{array}$ \\
\hline $\begin{array}{l}\text { length } \\
\text { learning }\end{array}$ & $\begin{array}{l}\text { micro-course, about } \\
\text { ten minutes }\end{array}$ & $\begin{array}{l}\text { forty-five } \\
\text { minutes }\end{array}$ \\
\hline $\begin{array}{l}\text { learning } \\
\text { motivation }\end{array}$ & $\begin{array}{l}\text { choosing courses for } \\
\text { needs and interests }\end{array}$ & required courses \\
\hline place and time & $\begin{array}{l}\text { learn anytime and } \\
\text { anywhere }\end{array}$ & $\begin{array}{l}\text { inside the } \\
\text { physical borders } \\
\text { of the campus }\end{array}$ \\
\hline $\begin{array}{l}\text { main } \\
\text { participant in } \\
\text { learning }\end{array}$ & $\begin{array}{l}\text { student-centered } \\
\text { learning }\end{array}$ & $\begin{array}{l}\text { teacher- } \\
\text { centeredness }\end{array}$ \\
\hline interactivity & $\begin{array}{l}\text { mu lti-dimensional } \\
\text { and multi-level } \\
\text { interactions }\end{array}$ & $\begin{array}{l}\text { face-to-face } \\
\text { teaching }\end{array}$ \\
\hline $\begin{array}{l}\text { curriculum } \\
\text { design }\end{array}$ & $\begin{array}{l}\text { meticulously } \\
\text { designed }\end{array}$ & poor creativity \\
\hline $\begin{array}{l}\text { class } \\
\text { presentation }\end{array}$ & $\begin{array}{l}\text { A short video } \\
\text { playback can be } \\
\text { watched repeatedly }\end{array}$ & $\begin{array}{l}\text { teachers give } \\
\text { lectures that are } \\
\text { finished once }\end{array}$ \\
\hline $\begin{array}{l}\text { Curriculum } \\
\text { evaluation } \\
\text { system }\end{array}$ & $\begin{array}{l}\text { system evaluation, } \\
\text { teacher evaluation } \\
\text { and peer-to-peer } \\
\text { assessments }\end{array}$ & $\begin{array}{l}\text { teacher } \\
\text { evaluation }\end{array}$ \\
\hline
\end{tabular}

Figure 1. Comparison of MOOCs to traditional teaching and learning

MOOCs break down economic, geographic, racial and gender barriers to higher education that embody the concept of equality of educational opportunity. MOOCs can improve the efficiency of online learning. Their key features include short videos and interactive quizzes that provide instant feedback[12]. Students can watch the video again and again and learn the same content repeatedly until they finally gets a good grasp of what it is it is conveying and finish their homework. Mutual evaluation and mutual learning give students a good chance to learn from others' experience easily. Ordinary students can improve their learning performance by using a combination of traditional teaching and learning in the course of learning. Students in colleges and universities can improve their academic performance by blended learning through the combination of the traditional teaching and independent learning in MOOCs.

Although people have different opinions on the development foreground and influence of MOOCs, one thing is for sure about MOOCs: the spiritual core of 
MOOCs, namely, high quality, open, innovation and independent spirit fits very highly with people's pursuit of higher education. Based on these ideas, MOOCs in colleges and universities in China are developing very quickly.

\section{OPPORTUNITIES AND CHALLENGES FACED BY CHINESE HIGHER EDUCATION}

\section{A. Build a New Pattern of localized MOOCs in China}

After Fudan University and Shanghai Jiaotong University joined Coursera, they began to provide excellent courses in Chinese or English to the Courser platform. On October 10, 2013, Tsinghua University officially launched the first global Chinese language MOOCs platform, namely "Online School" (WWW. Xuetangx. Com). This is the first attempt on MOOCs in China, bringing the hope and dawn to the development of Chinese higher education. So far 19 courses have been put on the network platform of "On line School". Since then, the other colleges and universities in China have set out to explore the new pattern of localized MOOCs. Shanghai has established the specialized agencies and actively promoted the development of high quality teaching resources among 30 member universities. The course sharing alliance between the eastern and western universities was launched by Chongqing University in order to learn advanced experience of MOOCs abroad. Take "the construction of national excellent network course" as an example, and the classroom teaching materials had reached to ten thousand since 2003. The construction target of the Twelfth Five-Year Plan in China is that institutions of Higher Education have to put 1000 open video courses and 5000 resource sharing courses on the internet. In a word, all these courses should being oriented towards China, serving education, spreading over society and going international" [17] that is the new pattern of localized MOOCs in China.

\section{B. Improve the Teaching Quality with the aid of MOOCs}

In MOOCs, people learn differently from one another, at different speeds and with different techniques. This is something that standard education models do not cater to[13].A lthough the educational reform has been carried out for many years, little headway has been made. For the mo ment, most colleges and universities in China still adopt the traditional classroom teaching model. The industries are changing so teachers in the institutes of higher learning should really take action to improve the teaching methods by which researchers prepare people are more than outdated. Teachers should make a bold attempt, bringing MOOCs to the campus and melting them into the teaching process. In China, the traditional university classroom is very serious and quiet. Often the teacher will lecture for a whole class. So the student just need listen for a whole class. It is a kind of inculcation education[14]. The emergence of MOOCs give teachers a good chance to try flipped classroom pedagogy, a hybrid educational model where students watch video lectures in advance and do "homework" and interact with a faculty member during actual classroom meetings [15]. Teachers should make full use of MOOCs platforms, assigning the homework ahead of time and giving students websites to look up in their spare time and ask students to preview and master the basic knowledge. Make sure the classroom is the place where teachers should inspire students to create positive thinking and give them more chances to discuss the is sues related to a certain topic and voice their opinions. The new teaching mode can change the traditional roles of students and teachers fundamentally. Students are not passive receivers any more. They will be in the dominant position and teachers play the leading role. Teachers are not lecturer any more. They will become real inspirators and motivators. Students will be free from the passive cramming method of teaching and they will actively gain knowledge. Learning will become more efficient and as a result, the teaching quality will be improved like a rising tide.

MOOCs have demonstrated their most effective role in supplementing the "flipped classroom" abroad. San Jose State University (SJSU) set a good example to us. SJSU conducted its own experiment to test the flipped clas sroom when it partnered with EdX to offer three versions of an introductory course in electrical engineering. In one flipped class, students watched online videos created by MIT faculty as an open MITx course (the MIT model of $\mathrm{EdX}$ ) and then came in to class for short lectures with SJSU faculty and group activities during class time. "The principal benefits are that students cannot fall behind because they must complete the homework to keep up with the classwork, which is done in groups, so those who fail to keep up immediately stick out," wrote an SJSU spokeswoman in an e-mail. The other two sections were conventional face-to-face classrooms. The outcome: 91 percent of students passed in the flipped course, compared to only 55 percent and 59 percent in the face-to-face clas srooms.

According to McKinsey, the management consulting firm, the flipped classroom is one of the forms of hybrid learning that will define higher education's future. Students who can afford to pay more will learn in a "campuscentric" environment, in which lectures are shown online and small-group discussions occur in brick-and-mortar classrooms. The other far less costly model is "digitalcentric," in which education occurs mainly online but might be complemented by self-organized study groups, as is already happening with MOOCs[16].

Chinese teachers should not miss out on a chance to get involved in the future of MOOCs on campus. Researchers should learn the ripe experiences abroad for reference and take full advantage of MOOCs to create a new teaching mode with distinct Chinese characteristics so as to improve the teaching quality.

\section{Challenges beyond MOOCs Faced By Chinese Higher Education}

MOOCs bring a full range of challenges and impact to Chinese high school teachers. In addition to the higher professional knowledge and the capability to use the up-todate information technology, high school teachers must change the way of thinking and redefine their own roles. Furthermore, MOOCs will thoroughly change the situation where teachers did the teaching job alone as before. Teachers must have the strong team cooperation spirit. Therefore, integration of teacher resources and promotion of team building are the inevitable trend of modern teacher's professional development in the era of MOOCs. 
This professional development trend has two advantages. First, it can promote the development of teachers' specialization and integrated management services that is required to create the intelligent teaching service system supported by the information technology in order to minimize teachers' repetitive work and promote the formation and development of teachers cooperation team across time and space. Second, the new relationship between teachers and students and the new relationship among learning partners appeared in the MOOCs trend based on large data, which has already broken down the barriers between teachers and students. Students can connect and collaborate globally in the MOOCs, directing their peer's learning and helping one another which can cultivate the students' service consciousness and promote the service spirit and enhance their own abilities at the same time. The era of MOOCs provides Chinese university teachers a good opportunity for innovative professional development. Researchers should take action to meet new challenges and seek better development opportunities.

\section{CONCLUSIONS}

The emergence of MOOCs has unquestionably changed the face of education, but one thing is certain that MOOCs can't completely replace campus education. MOOCs have somewhat threatened or put the traditional system of education to the test [18] so traditional education must take measures to evolve under a fast-paced development of new technologies. Professor Fan $\mathrm{Lu}$, vice president of Wenzhou Medical College, said: “MOOCs can replace some weak institutions. If universities are strong, they don't need to worry[19]." If weak institutions want to survive, they must optimize the old way of doing things, for example, changing the traditional collegiate experience that is still framed as sequential four-year, semester-based experience that happens directly after high school. The opportunity to leverage new tools in redefining the collegiate campus experience is massive. As long as weak institutions don't sit still waiting for death but actively look for ways to change the status quo and get improvement, they will have a better development with the help of MOOCs.

\section{REFERENCES}

[1] Ivy Wigmore. Massive open online course(MOOC). August 2013.

[2] Dumitru RĂDOIU. Organization and Constraints of a Recommender System for MOOCS[J]. Scientific Bullet in of the "Petru Maior" University of Tîrgu Mure. Vol. 11 (XXVIII) no. 1, 2014, p 51-59.

[3] Dewey 1938. Spectoret al. 2014.

[4] J. Michael Spector. Remarks on MOOCs and Mini-MOOCs[J]. Education Tech Research Dev . 2014, 62:385-392.

[5] Margaret Weigel. MOOCs and online learning. Research roundup. $\begin{array}{ll}\text { January } 22, & 2014 .\end{array}$ http://journalist sresource.org/studies/societ y/educat ion/moocsonline-learning.

[6] Valerie Strauss. Are MOOCs hyped?November 23, 2012. http://www.washingtonpost.com/blogs/answersheet/wp/2012/11/23/are-moocs-hyped/.

[7] http://net.educause.edu/ir/library/pdf/eli7078.pdf).

[8] Katherine Forestier. China's new MOOCs could be a double-edged sword. November 2013 Issue No:294. http://www.university worldnews.com/article.php?story $=20131101$ 154620288).

[9] http://education.stateuniversity.com/pages/1 868/Comenius-Johann1592-1670.html.

[10] http://baike.sogou.com/v141799.htm.

[11] T.C. Pong. Development and Challenges Beyond the MOOCs. July 9,2013.http://www.docin.com/p-721908397.html.

[12] Mary Beth Marklein.Universities bolster MOOCs for online learning

[13] http://www.usatoday.com/story/news/nation/2013/05/30/universitie s-coursera-moocs-online-learning/2371421/.

[14] Guo Ying-Jian. MOOCs and the Future of China's Higher Education[J]. Journal of Higher Education Management, 2014, $8(5): 29-33$.

[15] Chen Bingbing. MOOCs: Contributions and Dilemmas.Computerassisted Foreign Language Education[J]. No. 157,May 2014:38-43.

[16] http://wenku.baidu.com/view/88698e0390c69ec3d5bb75df.html.

[17] Curtis Kendrick and Irene Gashurov. Share Log in to Recommend. November 4, 2013. http://www.educause.edu/ero/article/librariestime-moocs.)

[18] Alan Garber. Harvard Provost Alan Garber Reflects on the HarvardX/edX Anniversary. HarvardX, May 20, 2013.

[19] What Do MOOCs Mean for TraditionalEducat ion?http://examinedexistence.com/what-domoocs-mean-for-traditional-education/.

[20] Katherine Forestie. China's new MOOCs could be a double-edged sword. No.294, November 2013.

[21] http://www.universityworldnews.com/article.php?story=20131101 154620288. 